\title{
StATISTIC RESEARCHING METHODS APPLIED TO THE IMPLEMENTATION OF TPM IN THE AUTOMOTIVE INDUSTRY OF ROMANIA
}

\author{
CAlefariu, G.; POPESCU, R.; TOMA, V. \& SARBU, F.
}

Abstract: Within this paper the TPM concept, applied to a large industrial scale of the advanced countries is presented and a researching method for applying it in the Romanian automotive industry is drafted. The research is made on grounds of the general economical statistic principles and the present management concepts.Researching aims are laid out, statistic collectivity is defined and than, by random methods, the sample is defined. Finally the questionnaire and its accompanying appendix is drafted.

Key words: TPM, maintenance, management, automotive
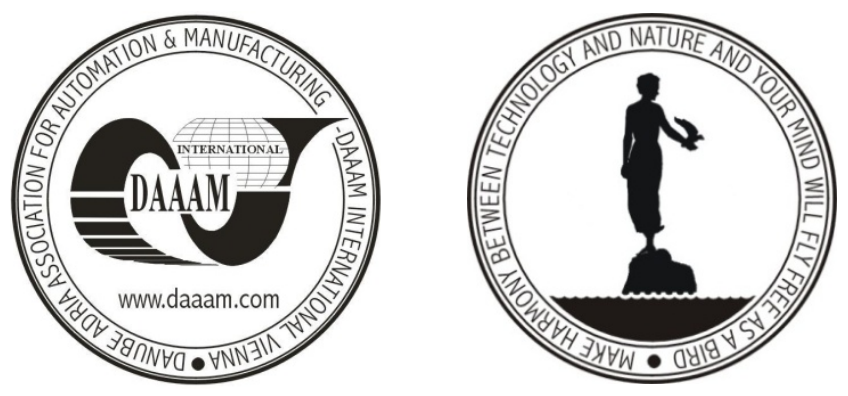

Authors' data: Authors' data: Prof. Calefariu, G[avrila]*; Popescu, R[adu]**; Ph.D Student Toma, V[ictoria]***; Dr. Sarbu, F[lavius]****, *Transilvania University of Brasov, 8 Morii St., 507055, Cristian, RO, **SC Stabilus SRL Romania, 130 Lunga St., 507055, Cristian, RO, ***Transilvania University of Brasov, M. Viteazul, No. 5, Brasov, Romania, 2200, Brasov, RO, ****Transilvania University of Brasov, 10 Bld. Garii, 500203, Brasov, RO, gcalefariu@unitbv.ro, popescu_crist@yahoo.com, sflavius@unitbv.ro,vtoma@unitbv.ro

This Publication has to be referred as: Calefariu, G[avrila]; Popescu, R[adu]; Toma, V[ictoria] \& Sarbu, F[lavius] (2008). Statistic Researching Methods Applied to the Implementation of TPM in the Automotive Industry of Romania, Chapter 16 in DAAAM International Scientific Book 2008, pp. 185-196, B. Katalinic (Ed.), Published by DAAAM International, ISBN 978-3-901509-66-7, ISSN 1726-9687, Vienna, Austria

DOI: $10.2507 /$ daaam.scibook.2008.16 